\title{
Multiplex PCR Assays for Species Discrimination of Cymbopogon citratus (DC.) Stapf and C.nardus (L.) Rendle, Two Common 'Serai' (Lemon Grass) Species in Peninsular Malaysia
}

(Asai ‘Multiplex PCR' bagi Membezakan Cymbopogon citratus (DC.) Stapf dan C. nardus (L.) Rendle, Dua Spesies Serai yang Biasa Diperoleh di Semenanjung Malaysia)

\author{
Wei Lun NG, SweE KeONG YeAP, Nur SyAZANA MOHAMEd ABU BAKAR, \\ WAN NURFATIN WAN MOHD JAAFAR \& SOON GUAN TAN*
}

\begin{abstract}
Aromatic grass species Cymbopogon citratus ('serai biasa/serai makan') and C. nardus ('serai wangi') can be commonly found throughout Peninsular Malaysia. C. citratus is used in traditional Malaysian cooking and brewed as tea, while C. nardus is used in traditional medicine for external application and in insect repellents. Due to similar morphologies, it can be difficult to tell apart the species at times. Based on DNA sequence alignments of three chloroplast DNA intergenic spacer regions, namely atpB-rbcL, trnH-psbA and trnL-trnF, we designed species-specific primers for multiplex $P C R$ assays for rapid species discrimination between $\mathrm{C}$. citratus and $\mathrm{C}$. nardus. The method described here makes use of simple molecular techniques that are time-and cost-effective for large-scale application. Such an assay will be useful for the quality assurance of food and medicinal products.
\end{abstract}

Keywords: Food quality assurance; herb; molecular identification; serai makan; serai wangi

ABSTRAK

Spesies rumput aromatik Cymbopogon citratus ('serai biasa/serai makan') dan C. nardus ('serai wangi') biasa diperoleh di sekitar Semenanjung Malaysia. C. citratus digunakan dalam masakan tradisi Malaysia dan direbus sebagai teh, manakala C. nardus digunakan dalam perubatan tradisi untuk aplikasi luaran dan penghalau serangga. Oleh kerana morfologinya yang sama, kedua-dua spesies ini sukar untuk dibezakan. Berdasarkan penjajaran jujukan DNA daripada tiga 'intergenic spacer' DNA kloroplas iaitu atpB-rbcL, trnH-psbA dan trnL-trnF, 'primer' khusus telah dihasilkan untuk kaedah 'multiplex PCR' bagi membezakan C. citratus dan C. nardus dengan cepat. Kaedah yang digunakan melibatkan teknik molekul ringkas yang menjimatkan masa dan kos untuk penggunaan berskala besar. Kaedah ini berguna dalam proses penjaminan kualiti produk makanan dan ubat-ubatan.

Kata kunci: Herba; jaminan kualiti makanan; pengesahan secara molekul; serai makan; serai wangi

\section{INTRODUCTION}

Cymbopogon is a genus under the Poaceae or the grass family comprising of species that are rapidly growing and possess distinctive aromatic foliage. The species are indigenous in tropical and semi-tropical areas of Asia and are cultivated in other tropical regions of the world (Akhila 2010). In Peninsular Malaysia, two Cymbopogon species, C. citratus (lemon grass) and C.nardus (citronella grass) can be commonly found. Locally known as 'serai biasa' or 'serai makan' (literally, the common lemongrass or edible lemon grass), C. citratus is used as a herb in day-to-day preparation of local Malaysian dishes as well as being brewed as tea; while 'serai wangi' (literally, fragrant lemon grass; $C$. nardus) is traditionally used topically (i.e. not ingested), such as in the preparation of bath water meant for women undergoing confinement and as a natural insect repellent (pers. comm. Wei Lun $\mathrm{Ng}$ ). The essential oils derived from both $C$. citratus and $C$. nardus have been shown to possess insect repellent properties, although in most cases the essential oil from $C$. nardus seems to be more effective (Maia \& Moore 2011). Due to their uses, both species can be found planted around housing areas in Peninsular Malaysia, although $C$. citratus is more frequently spotted and its stalks are also sold in local wet markets (pers. obs. Wei Lun $\mathrm{Ng}$ ).

Based on our observations in the field, mature bushes of both species have only slight differences: $C$. citratus has leaves that are light green in color, are narrower $(\sim 1.4$ $\mathrm{cm})$ and shorter $(\sim 95 \mathrm{~cm})$ and its bush grows to a height of $\sim 130 \mathrm{~cm}$; compared to $C$. nardus which has leaves that are dark green in colour, are broader $(\sim 2.7 \mathrm{~cm})$ and longer $(\sim 150 \mathrm{~cm})$ and its bush grows to a height of $\sim 150 \mathrm{~cm}$. Despite these differences, such continuous (quantitative) traits can be variable in plants (Sultan 2000) and the species can be difficult to tell apart when the plants are young or when the leaves are not present (very often only the stalk 
is retained when being sold at the wet markets). A DNA marker for species discrimination between C. citratus and C. nardus will be useful for quality assurance of food and medicinal products, especially when morphological data is not available.

While DNA barcoding by DNA sequencing is accurate and is gaining popularity as a tool for species identification, its cost limits the number of samples to be screened. Here we describe an easy, rapid and inexpensive multiplex PCR assay for molecular species discrimination of $C$. citratus and $C$. nardus through amplification of species-specific DNA fragments based onchloroplast DNA intergenic spacer regions.

\section{MATERIALS AND METHODS}

\section{SAMPLING AND DNA EXTRACTION}

Three samples each of $C$. citratus and $C$. nardus were obtained from different locations within Peninsular Malaysia (Terengganu: Dungun, Melaka: Ayer Keroh and Negeri Sembilan: Seremban for C. citratus; Selangor: Kajang and Serdang and Kedah: Nyak Gam for C.nardus; the exact sampling locations are shown in a map in Figure 1) to maximise the coverage of any genetic variation possibly present in the species. The samples collected comprised of either the leaf or the stalk or both, that were frozen prior to DNA extraction.

Genomic DNA (gDNA) was extracted from $100 \mathrm{mg}$ leaf/stalk material using the cetyl trimethylammonium bromide (CTAB) extraction method. The extracted gDNA was subsequently used as template for PCR amplification.

\section{PCR AMPLIFICATION AND DNA SEQUENCING}

Three chloroplast DNA (cpDNA) regions: the atpB-rbcL intergenic spacer (IGS), trnH-psbA IGS and trnL-trn FIGS regions were PCR-amplified from the gDNA of both $C$. citratus and $C$. nardus. The universal primers atpB-1 (5' -ACATCKARTACKGGACCAATAA-3') and rbcL-1 (5'-AACACCAGCTTTRAATCCAA-3') by Chiang et al. (1998), trn (5'-CGCGCATGGTGGATTCACAATCC-3') and psbA1 (5'-GTTATGCATGAACGTAATGCT-3') by Kress et al. (2005), trnL-c (5'-CGAAATCGGTAGACGCTACG-3') and trnF-f (5'-ATTTGAACTGGTGACACGAG-3') by Taberlet et al. (1991), respectively, were used. PCR

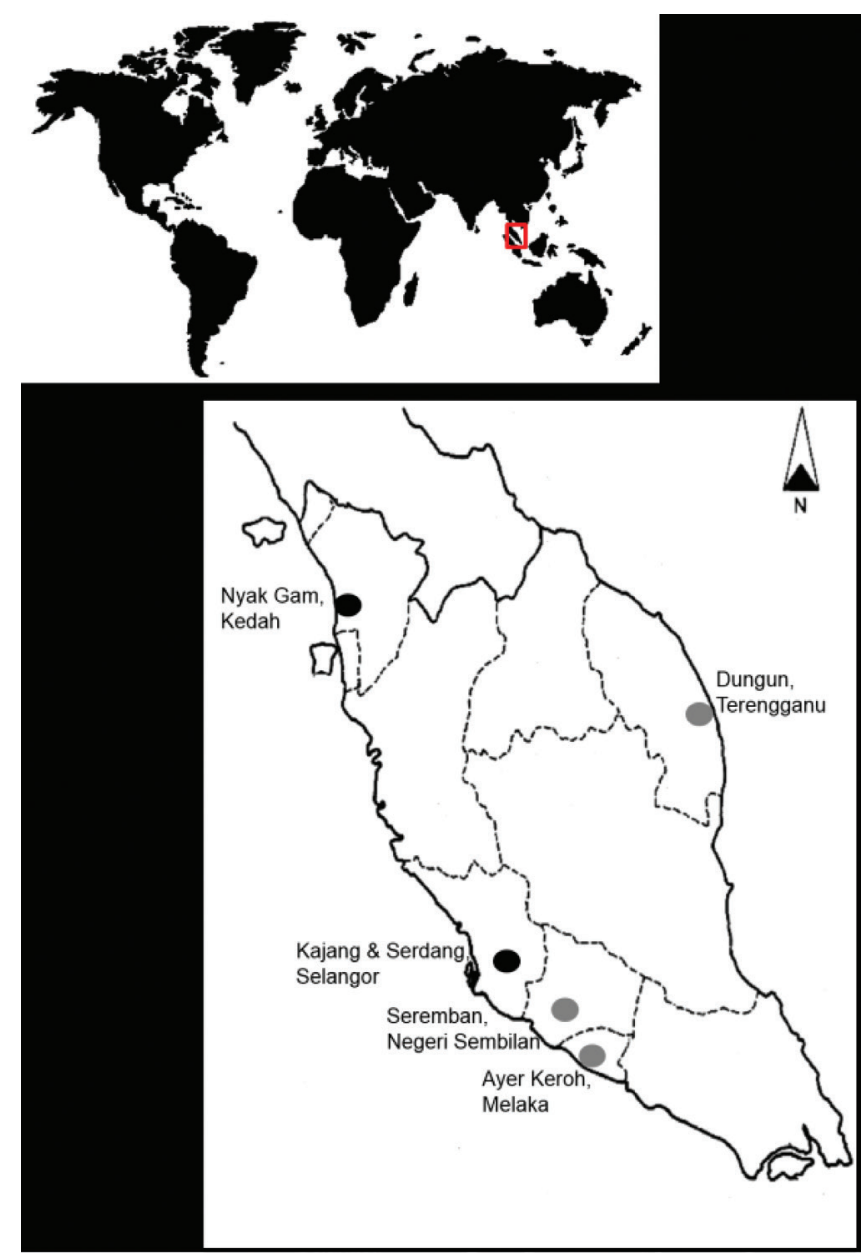

FIGURE 1. Map showing the sampling locations for the three $C$. citratus and three $C$. nardus samples used in this study. Grey circles represent sampling locations for $C$. citratus; black circles represent sampling locations for $C$. nardus 
amplifications were performed in $20 \mu \mathrm{L}$ reaction mixtures, each containing 30-50 ng of gDNA as template, $1 \mu \mathrm{M}$ of each primer and $10 \mu \mathrm{L}$ of $\mathrm{NEXpro}^{\mathrm{TM}}$ e PCR $2 \times$ master mix (NEX Diagnostics). The PCR reaction profile comprised of an initial denaturation of $3 \mathrm{~min}$ at $95^{\circ} \mathrm{C}$, followed by 30 cycles of $30 \mathrm{~s}$ at $95^{\circ} \mathrm{C}, 30 \mathrm{~s}$ at $50^{\circ} \mathrm{C}$ and $2 \mathrm{~min}$ at $72^{\circ} \mathrm{C}$ and finally an extension step of $7 \mathrm{~min}$ at $72^{\circ} \mathrm{C}$.

The purified PCR products were used for direct sequencing with the BigDye ${ }^{\circledR}$ Terminator ver. 3.1 Cycle Sequencing Kit (Applied Biosystems) and the products were analysed on an ABI3730xl DNA Analyzer (Applied Biosystems) through services provided by First BASE Laboratories Sdn. Bhd.

\section{DATA ANALYSIS AND PRIMER DESIGN}

The cpDNA sequences were edited using the software ATGC ver. 6.0 (GENETYX CORPORATION) and aligned using Clustal W (Thompson et al. 1994) implemented in MEGA 5 (Tamura et al. 2011) and corrected manually.

Based on the alignment of the cpDNA sequences, single nucleotide polymorphisms (SNPs) specific to each of the species were identified. Primers specific to the DNA sequence of $C$. nardus were then designed: the 3' ends of the primers were designed to perfectly match the SNP specific to $C$. nardus. An additional mismatch was introduced at the third nucleotide position from the 3' ends to increase the power of selective amplification during PCR, as in $\mathrm{Ng}$ and Szmidt (2013).

\section{RESULTS AND DISCUSSION}

\section{DNA SEQUENCE ALIGNMENT}

Three cpDNA IGS regions were first sequenced from one sample each of $C$. citratus and $C$. nardus. As the atpB$r b c L$ IGS region contained several long mononucleotide repeats which affected the efficiency of DNA sequencing, its sequences were not conclusive and excluded from subsequent analyses. Such conditions are due to the formation of stutter products, a common artifact during PCR amplification of long, repeated sequences (Clarke et al. 2001). DNA sequence alignments were thus performed separately for the remaining two IGS regions. No interspecific site polymorphism was found in the trnH-psbA IGS regions, while only one species-specific polymorphic site was found in the $\operatorname{trnL}-\operatorname{trnF}$ IGS region. The trnL-trnF IGS region of two more samples of each species was additionally sequenced and it was confirmed that the polymorphism was species-specific.

The DNA sequences for both species at the trnL-trnF (893bp) and trnH-psbA (573bp) IGS regions obtained in this study have been deposited in GenBank with accession numbers KT274018-KT274021.

\section{PRIMER DESIGN AND MULTIPLEX PCR}

Out of the three IGS regions, species-specific primers were successfully designed only for the trnL-trnF IGS region. Two primers, in opposite directions, were designed with their 3' ends anchoring at the polymorphic site specific for C. nardus (Figure 2). Multiplex PCR was conducted using any one of the two designed primers together with the trnL-c and trnF-f primers (a total of three primers per PCR reaction) on $C$. citratus and $C$. nardus samples. The two sets of primers (sets A and B) for multiplex PCR are shown in Table 1. PCR amplifications were performed in $10 \mu \mathrm{L}$ reaction mixtures, each containing 30-50 ng of gDNA as template, $0.5 \mu \mathrm{M}$ of each primer and $5 \mu \mathrm{L}$ of NEXpro $^{\text {TM }}$ e PCR $2 \times$ master mix (NEX Diagnostics). The PCR reaction profile comprised of an initial denaturation of $3 \mathrm{~min}$ at $95^{\circ} \mathrm{C}$, followed by 30 cycles of $30 \mathrm{~s}$ at $95^{\circ} \mathrm{C}, 30 \mathrm{~s}$ at 50 or $55^{\circ} \mathrm{C}$ and $2 \mathrm{~min}$ at $72^{\circ} \mathrm{C}$ and finally an extension step of $7 \mathrm{~min}$ at $72^{\circ} \mathrm{C}$. PCR amplicons were analysed by electrophoresis on $1.0 \%$ (weight/volume) agarose gel, stained with ethidium bromide and viewed under UV illumination.

The use of either set of primers yielded the intended banding patterns on the agarose gel (i.e. one band for $C$. citratus and two bands for $C$.nardus; their corresponding band sizes are listed in Table 1). The primers were tested on 8 other samples each of $C$. citratus and $C$. nardus collected from random sites in Peninsular Malaysia and the results were consistent in all cases. As shown in Figure 3, the targeted species-specific bands were clear and can be easily sized on a $1.0 \%$ agarose gel, despite of some amount smearing/unspecific amplification that did not affect the quality/visualization of the target bands.

Simple multiplex PCR assays have been developed for the reliable identification of a myriad of species, including microbial (Settanni \& Corsetti 2006), animal (Fajardo et al. 2010; Lin \& Hwang 2008) and plant species (James et al. 2003; Ng \& Szmidt 2013), the identification of which through morphology or various tests were initially complicated tasks. With $C$. citratus and $C$. nardus being commonly used in the food and natural product industries,

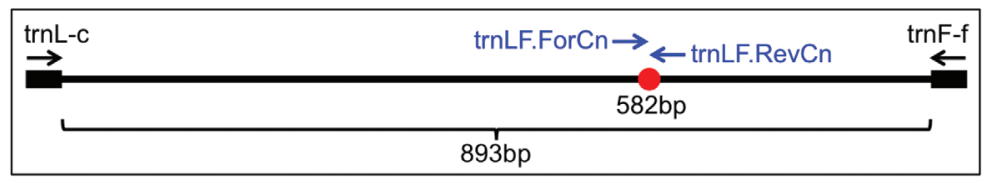

FIGURE 2. A schematic diagram showing the positions and directions of the primers used in the multiplex PCR assays. The red dot shows the location of the species-specific site mutation between C. citratus and $C$. nardus at the amplified trnL-trnF IGS region 
TABLE 1. PCR primers used in the multiplex assays developed in this study

\begin{tabular}{|c|c|c|}
\hline Primer set & Primer sequences & $\begin{array}{l}\text { Target species } \\
\text { (no. of bands; approx. band size(s)) }\end{array}$ \\
\hline \multirow[t]{2}{*}{ A } & $\begin{array}{l}\operatorname{trnL-c} \\
\text { 5'-CGAAATCGGTAGACGCTACG-3' }\end{array}$ & $\begin{array}{l}\text { C. citratus } \\
\text { (1 band; 950bp) }\end{array}$ \\
\hline & $\begin{array}{l}\operatorname{trnF-f} \\
\text { 5'-ATTTGAACTGGTGACACGAG-3' } \\
\text { trnLF.ForCn } \\
\text { 5'-GGGTTTAAGATTCACTAGCTㄸC-3' }\end{array}$ & $\begin{array}{l}\text { C. } \text { nardus } \\
\text { ( } 2 \text { bands; } \sim 350 \mathrm{bp} \text { and } \sim 950 \mathrm{bp})\end{array}$ \\
\hline \multirow[t]{3}{*}{ B } & $\begin{array}{l}\operatorname{trnL}-\mathrm{c} \\
\text { 5'-CGAAATCGGTAGACGCTACG-3' }\end{array}$ & $\begin{array}{l}\text { C. citratus } \\
\text { (1 band; } \sim 950 \mathrm{bp})\end{array}$ \\
\hline & $\begin{array}{l}\operatorname{trnF-f} \\
\text { 5'-ATTTGAACTGGTGACACGAG-3', }\end{array}$ & $\begin{array}{l}\text { C. } \text { nardus } \\
\text { ( } 2 \text { bands; } \sim 630 \mathrm{bp} \text { and } \sim 950 \mathrm{bp})\end{array}$ \\
\hline & $\begin{array}{l}\operatorname{trnLF} \cdot \operatorname{RevCn} \\
5 \text { '-CCTTTGTGAAAGAGTAGAATCAA-3, }\end{array}$ & \\
\hline
\end{tabular}

(a)

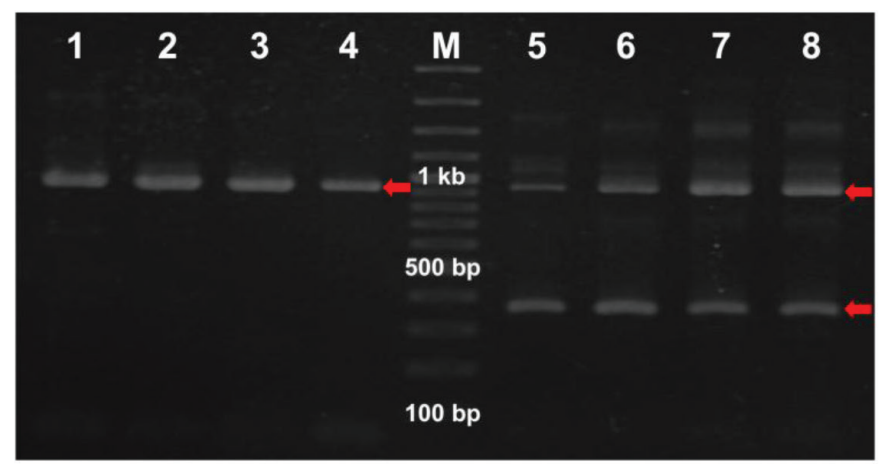

(b)

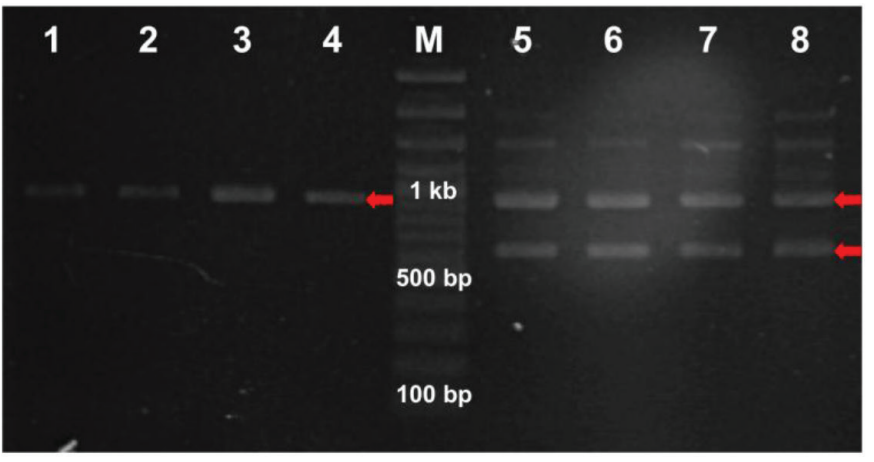

FIGURE 3. Multiplex PCR amplification results of $C$. citratus and $C$. nardus samples using (a) primer set A and (b) primer set

B. Lane $M=100$ bp DNA ladder; lanes 1-4 = C. citratus; lanes 5-8 $=$ C. nardus. Red arrows show the expected bands

we believe that the method described in this study will provide a way for increased product quality assurance through molecular species identification.

\section{ACKNOWLEDGEMENTS}

The authors thank the anonymous reviewers for providing helpful comments on earlier drafts of the manuscript. 


\section{REFERENCES}

Akhila, A. 2010. Essential Oil-Bearing Grasses: The genus Cymbopogon. Florida: CRC Press.

Chiang, T.Y., Schaal, B.A. \& Peng, C.I. 1998. Universal primers for amplification and sequencing a noncoding spacer between the $a t p B$ and $r b c L$ genes of chloroplast DNA. Bot.Bull.Acad. Sin. 39: 245-250.

Clarke, L.A., Rebelo, C.S., Goncalves, J., Boavida, M.G. \& Jordan, P. 2001. PCR amplification introduces errors into mononucleotide and dinucleotide repeat sequences. J. Clin. Pathol.: Mol. Pathol. 54: 351-353.

Fajardo, V., Gonzalez, I., Rojas, M., Garcia, T. \& Martin, R. 2010. A review of current PCR-based methodologies for the authentication of meats from game animal species. Trends in Food Sci. \& Tech. 21(8): 408-421.

James, D., Schmidt, A., Wall, E., Green, M. \& Masri, S. 2003. Reliable detection and identification of genetically modified maize, soybean, and canola by multiplex PCR analysis. $J$. Agric. Food Chem. 51(20): 5829-5834.

Kress, W.J., Wurdack, K.J.,Zimmer, E.A., Weigt, L.A. \& Janzen, D.H. 2005. Use of DNA barcodes to identify flowering plants. PNAS 102(23): 8369-8374.

Lin, W.F. \& Hwang, D.F. 2007. A multiplex PCR assay for species identification of raw and cooked bonito. Food Control 19(9): 879-885.

Maia, M.F. \& Moore, S.J. 2011. Plant-based insect repellents: a review of their efficacy, development and testing. Malaria Journal 10(Sup 1): S11.

Ng, W.L. \& Szmidt, A.E. 2013. A simple and inexpensive molecular assay for species identification of Indo-West Pacific Rhizophora mangroves for conservation and management. Conservation Genet. Resour. 5: 1059-1061.

Settanni, L. \& Corsetti, A. 2006. The use of multiplex PCR to detect and differentiate food- and beverage-associated microorganisms: A review. J. Microbiological Methods 69(1): 1-22.
Sultan, S.E. 2000. Phenotypic plasticity for plant development, function and life history. Trends in Plant Sci.5(12): 537-542.

Taberlet, P., Gielly, L., Pautou, G. \& Bouvet, J. 1991. Universal primers for amplification of three non-coding regions of chloroplast DNA. Plant Mol. Biol. 17: 1105-1109.

Tamura, K., Peterson, D., Peterson, N., Stecher, G., Nei, M. \& Kumar, S. 2011. MEGA5: molecular evolutionary genetics analysis using maximum likelihood, evolutionary distance, and maximum parsimony methods. Mol. Biol. Evol. 28: 2731-2739.

Thompson, J.D., Higgins, D.G. \& Gibson, T.J. 1994. CLUSTAL $\mathrm{W}$ : Improving the sensitivity of progressive multiple sequence alignment through sequence weighting, position-specific gap penalties and weight matrix choice. Nucleic Acids Res. 22 4673-4680.

Wei Lun Ng, NurSyazana Mohamed Abu Bakar, Wan Nurfatin Wan Mohd Jaafar \& Soon Guan Tan* Department of Cell and Molecular Biology

Faculty of Biotechnology and Biomolecular Sciences Universiti Putra Malaysia 43400 Serdang, Selangor Darul Ehsan Malaysia

Swee Keong Yeap Institut Biosains, Universiti Putra Malaysia 43400 Serdang, Selangor Darul Ehsan Malaysia

*Corresponding author; email: sgtan@upm.edu.my

Received: 30 April 2015

Accepted: 28 September 2015 